\title{
Immobilization of lipase in silica gel from rice husk ash and its activity assay to hydrolyze palm oil
}

\author{
Krismonalia Rizki, Deni Pranowo*, and Tri Joko Raharjo \\ Department of Chemistry, Faculty of Mathematics and Natural Science, Universitas Gadjah Mada, \\ Jl. Sekip Utara BLS 21, Bulaksumur, Yogyakarta, 55281, Indonesia.
}

\begin{abstract}
A free lipase is one of the biocatalysts used for industrial applications, especially to catalyze the hydrolysis of palm oil. However, it is unstable in an extreme condition so it is easy to denature. Immobilization of lipase improve the enzyme's stability since the cage of the immobilization matrix around the lipase can minimalize denaturation. Silica gel is the most chosen matrix because of its high thermal stability and inertness. Lipase was immobilized in silica gel extracted from rice husk ash. Silica gel was prepared in a sodium silicate solution. Sol-gel process occurred when phosphoric acid was added into the sodium silicate solution until it reached a $\mathrm{pH}$ of 7 . The immobilization process was initiated by reacting lipase in Phosphate Buffer Solution (PBS) added to the sol solution to produce hydrogel. Hydrogel was got into the dry process to form xerogel. The activity assay was conducted in the hydrolysis reaction by titrimetric method. The immobilized lipase resulted had an immobilization percentage of $67.71 \%$ and reusability for 6 cycles.
\end{abstract}

Keywords: Hydrolysis, immobilization, lipase, silica, sol-gel

\section{Introduction}

Productivity is the main term for reaching efficiency and sustainability on a major scale in industrial activities. Therefore, an action for maintaining productivity without decreasing its quality is needed for the product and its efficiency. The usage of the catalyst is popular in industrial application due to its roles for the chemical process [1]. Even so, the usage of any catalyst such as acid, base, or metal, may increase the environmental issues in terms of the high cost of waste management. An environmental-friendly catalyst may prevent these bad issues since it can be reused in easy waste management. One of these catalysts is a biocatalyst called enzyme [2]. As the major product of biotechnology, the enzyme has been widely used in industrial applications. The enzymatic process is involved in the mechanic or chemical process. An enzyme can be recommended catalyst in industrial scale since it provides some advantages, like conducting reaction by mild operation, containing specificity and selectivity, and minimalizing the environmental issues. Additionally, they can catalyze efficiently [3]. However, an enzyme is unstable in certain conditions. It cannot work in an extreme condition so it will be denatured. In other words, the use of the enzyme is not as wide as the other major catalyst [4]. Immobilization of enzyme can improve the stability in extreme conditions as the matrix succeeds in trapping enzyme. Additionally, an immobilized enzyme is reusable without decreasing its activity drastically. The decrease may be caused by the instability of the enzyme's active site [5]. Immobilized lipase also gives a higher conversion of triglyceride to free fatty acid than free lipase [6,7].

Rice husk is one of the composite materials and natural biopolymers composed of lignin, cellulose, hemicellulose, and silicon dioxide [8]. Generally, rice husk ash is produced from the calcination process of rice husk. Rice husk ash can be used as an economical source for immobilizing enzymes. It is more efficient, renewable, and it contains $91.43 \%$ of silicon dioxide $\left(\mathrm{SiO}_{2}\right)$ [9]. The silica compound in the amorphousformed has a small particle size and high surface area as it has a function for adsorption of a molecule. One of the amorphous silica is silica gel, which can be synthesized by sol-gel. Mostly, silica gel is used as a precursor due to its high thermal stability, inability to expand, inertness, and transparency. Silica sol-gel matrices can be used in the encapsulation of enzymes without changing its structure. The enzymes are stabilized by the silica matrices encapsulation, which creates the framework around the enzymes to prevent aggregation, dissociation, and degradation [10].

\section{Materials and methods}

\subsection{Materials}

The rice husk was taken from agricultural waste. The lipase powder was purchase from Sigma, palm oil, and all chemicals with pro analysis grade (Merck), i.e. sodium hydroxide $(\mathrm{NaOH})$, sodium chloride $(\mathrm{NaCl})$,

\footnotetext{
* Corresponding author: maspranowo@ugm.ac.id
} 
potassium chloride $(\mathrm{KCl})$, disodium hydrogen phosphate $\left(\mathrm{Na}_{2} \mathrm{H}_{2} \mathrm{PO}_{4}\right)$, potassium dihydrogen phosphate $\left(\mathrm{KH}_{2} \mathrm{PO}_{4}\right)$, copper sulfate pentahydrate $\left(\mathrm{CuSO}_{4} .5 \mathrm{H}_{2} \mathrm{O}\right)$, potassium sodium tartrate $\left(\mathrm{KNaC}_{4} \mathrm{H}_{4} \mathrm{O}_{6} \cdot 4 \mathrm{H}_{2} \mathrm{O}\right)$, Bovine Serum Albumin (BSA), phenolphthalein indicator, hydrochlo-ride $(\mathrm{HCl}) 37 \%$, phosphoric acid $\left(\mathrm{H}_{3} \mathrm{PO}_{4}\right) 85 \%$, ethanol, n-hexane, boron trifluoride $\left(\mathrm{BF}_{3}\right)$ in methanol.

\subsection{Methods}

The method used in this study was in line with the previous research [11] which involved sol-gel process in the protein immobilization process.

\subsubsection{Preparation of rice husk ash}

Rice husk was rinsed then dried under the sunlight. After getting dried, the rice husk was heated until it changed into black charcoal. The heating had to be stopped when there was no more carbon monoxide gases. Charcoal was then calcined in the furnace $\left(4 \mathrm{~h}, 700{ }^{\circ} \mathrm{C}\right)$ and crushed on the 200 mesh sieve. After that, $5 \mathrm{~g}$ of rice husk ash were washed with $1 \mathrm{M}$ hydrochloride for an hour. The ash solution had to be filtrated, washed, and dried completely.

\subsubsection{Preparation of sodium silicate}

Sodium silicate $\left(\mathrm{Na}_{2} \mathrm{SiO}_{3}\right)$ solution was synthesized by reacting $5 \mathrm{~g}$ of rice husk ash in $50 \mathrm{~mL}$ of $4 \mathrm{M}$ sodium hydroxide $(\mathrm{NaOH})$. It had to be boiled until changing into a viscous greyish black solution. Afterwards, it was poured on the porcelain evaporating dish and calcined under $700{ }^{\circ} \mathrm{C}$ for $1.5 \mathrm{~h}$. Sodium silicate solid was crushed and diluted in $100 \mathrm{~mL}$ demineralized water for $24 \mathrm{~h}$. The solution was filtrated. The filtrated one had yellowish brown colored with a $\mathrm{pH}$ of 13 .

\subsubsection{Immobilization of lipase in silica gel}

Phosphate Buffer Solution (PBS) was prepared by dissolving of $8 \mathrm{~g}$ of $\mathrm{NaCl}, 0.2 \mathrm{~g}$ of $\mathrm{KCl}, 1.44 \mathrm{~g}$ of $\mathrm{Na}_{2} \mathrm{HPO}_{4}$, and $2.4 \mathrm{~g}$ of $\mathrm{KH}_{2} \mathrm{PO}_{4}$ diluted in $1000 \mathrm{~mL}$ of distilled water. When the $\mathrm{pH}$ reached 6.8 to 7.0 , it was ready to initiate the immobilization process. Free lipase $(0.2 \mathrm{~g})$ was added to PBS $(1.02 \mathrm{~mL})$ so the concentration was $0.2 \mathrm{~g} \mathrm{~mL}^{-1}$. The sol-gel process involved acidification by adding $0.1 \mathrm{M}$ of phosphoric acid $\left(\mathrm{H}_{3} \mathrm{PO}_{4}\right)$ into $\mathrm{Na}_{2} \mathrm{SiO}_{3}$-lipase solution. Acidification stopped when it reached the $\mathrm{pH}$ of 7. A hydrogel of the immobilized enzyme had to be stirred frequently until it changed to be xerogel (dried hydrogel).

There were six variations of immobilization enzyme, consisting of two different techniques. Those variations were the ratio of [lipase]:[silica gel], as if [lipase] was constant for all ratios. They were $1: 1,1: 2$, and $2: 1$ for technique I, and 1:1(II), 1:2(II), and 2:1(II) for technique II. So, there was total of six immobilized enzymes whose codes were E1, E2, E3, E4, E5, and E6 consecutively. The comparison of two different techniques can be shown in Table. 2 .

\subsubsection{Determination of immobilized lipase in silica gel}

A biuret reagent was prepared by mixing $150 \mathrm{mg}$ of copper sulfate pentahydrate $\left(\mathrm{CuSO}_{4} .5 \mathrm{H}_{2} \mathrm{O}\right)$ and $150 \mathrm{mg}$ of potassium sodium tartrate $\left(\mathrm{KNaC}_{4} \mathrm{H}_{4} \mathrm{O}_{6}\right)$ with $50 \mathrm{~mL}$ of water in a $100 \mathrm{~mL}$ volumetric flask. After that, $30 \mathrm{~mL}$ of $\mathrm{NaOH} 10 \%$ was added into the solution followed by adding water to the limit of $100 \mathrm{~mL}$. A standard solution was prepared by dissolving $100 \mathrm{mg}$ of BSA in a $10 \mathrm{~mL}$ volumetric flask followed by the addition of water to the limit of $10 \mathrm{~mL}$, so the concentration of BSA standard solution was $10 \mathrm{mg} \mathrm{mL}^{-1}$. After that, $10 \mathrm{mg} / \mathrm{mL}$ BSA standard was diluted into $0.1 ; 0.25 ; 0.75 ; 1 ; 1.5$; and 2 $\mathrm{mg} / \mathrm{mL}$. Each standard solution was added with $4 \mathrm{~mL}$ of biuret reagent then incubated for $10 \mathrm{~min}$ at room temperature. The determination of initial lipase could be done by dissolving $70 \mathrm{mg}$ of lipase in $10 \mathrm{~mL}$ of PBS. The solution was mixed homogenously using a vortex. A blank solution was prepared by mixing $2.5 \mathrm{~mL}$ of $\mathrm{H}_{2} \mathrm{O}$. Biuret reagent ( $4 \mathrm{~mL}$ ) was added into each sample and blank solution, which was then incubated for $10 \mathrm{~min}$ at room temperature. The determination of immobilized lipase in silica gel was prepared by soaking the immobilized lipase in the PBS solution for an hour. The mixture was then separated by filtration. The soaking was done for four times in order to get four filtrates. From each filtrate $2.5 \mathrm{~mL}$ was taken, mixed with $4 \mathrm{~mL}$ of biuret reagent, and then incubated for $10 \mathrm{~min}$. The absorbance of standard solutions and sample was measured at $540 \mathrm{~nm}$ by UV-Visible spectrophotometer.

\subsubsection{Characterization of palm oil}

Palm oil $(0.25 \mathrm{~mL})$ was poured into the reacting tube, followed by $0.75 \mathrm{~mL}$ boron trifluoride in methanol. The solution was stirred at $60{ }^{\circ} \mathrm{C}$ for $1.5 \mathrm{~h}$ followed by cooled and extracted in $1.75 \mathrm{~mL} \mathrm{n}$-hexane, and then analyzed by GCMS.

\subsubsection{Activity assay for hydrolysis palm oil}

Palm oil $(0.5 \mathrm{~g})$ and $10 \mu \mathrm{L}$ of distilled water were added to $50 \mathrm{~mL}$ conical tube, and $\mathrm{n}$-hexane was poured to the limit of $10 \mathrm{~mL}$, followed by the addition of $0.15 \mathrm{~g}$ of free lipase. The solution was mixed using a shaker at room temperature for $2 \mathrm{~h}$, then separated using centrifugation. The supernatant got the addition of $10 \mathrm{~mL}$ of ethanol and 3 drops of phenolphthalein indicator. The solution was titrated by $0.05 \mathrm{M} \mathrm{NaOH}$. For the assay of immobilized lipase, the method was similar to above.

\section{Results and discussion}

\subsection{GCMS analysis}

For the activity assay of an enzyme, the molecular weight of palm oil had to be calculated. Based on GCMS analysis, palm oil contains myristic, palmitic, linolelaidic, oleic, and stearic alkyl. The molecular weight of palm oil can be calculated as the equation 
below. Using equation (1) and (2), the molecular weight of palm oil was $849.177 \mathrm{~g} \mathrm{~mol}^{-1}$.

$$
\begin{aligned}
& M r=173+3 \bar{R} \\
& \bar{R}=\sum_{n=1}^{n=5}\left(\text { Mr } \times \text { percentage }{ }_{n}\right.
\end{aligned}
$$

Table 1. Composition of methyl ester compound in palm oil

\begin{tabular}{lccc}
\hline $\begin{array}{c}\text { Alkyl of } \\
\text { Fatty Acid }\end{array}$ & $\begin{array}{c}\text { Molecular } \\
\text { Formula }\end{array}$ & $\begin{array}{c}\text { Molecular } \\
\text { Weight }\end{array}$ & $\begin{array}{c}\text { Percentage } \\
(\%)\end{array}$ \\
\hline Myristic & $\mathrm{C}_{13} \mathrm{H}_{27}$ & 183 & 0.99 \\
Palmitic & $\mathrm{C}_{15} \mathrm{H}_{33}$ & 211 & 42.15 \\
Linolelaidic & $\mathrm{C}_{17} \mathrm{H}_{31}$ & 235 & 9.40 \\
Oleic & $\mathrm{C}_{17} \mathrm{H}_{33}$ & 237 & 43.77 \\
Stearic & $\mathrm{C}_{17} \mathrm{H}_{35}$ & 239 & 3.69 \\
\hline
\end{tabular}

\subsection{Immobilization lipase in silica gel}

Certainly, there were differences among 6 immobilized enzymes. Even so, all of them had similar physical appearance, which was a yellowish-white powder. Their parameters can be shown in the table below.

Table 2. Parameter of immobilization enzyme

\begin{tabular}{ccccc}
\hline Sample & $\begin{array}{c}\text { Mass } \\
(\mathrm{g})\end{array}$ & $\begin{array}{c}\mathrm{Na}_{2} \mathrm{SiO}_{3} / \mathrm{H}_{2} \mathrm{O} / \\
\mathrm{H}_{3} \mathrm{PO}_{4} \\
(\mathrm{~mL})\end{array}$ & $\begin{array}{c}\text { Gelation } \\
\text { process } \\
\text { (minutes) }\end{array}$ & $\begin{array}{c}\text { Drying } \\
\text { process } \\
\text { (days) }\end{array}$ \\
\hline E1 & 0.4 & $2.0 / 0.6 / 1.4$ & 5 & 9 \\
E2 & 0.8 & $4.0 / 1.3 / 2.7$ & 5 & 13 \\
E3 & 0.2 & $1.0 / 0.3 / 0.7$ & 10 & 9 \\
E4 & 0.3 & $2.0 / 0 / 1.5$ & 9 & 10 \\
E5 & 0.8 & $4.0 / 0 / 3.1$ & 5 & 14 \\
E6 & 0.19 & $1.0 / 0 / 0.75$ & 20 & 10 \\
\hline
\end{tabular}

Technique I had $\mathrm{H}_{2} \mathrm{O}$ in a sol-gel process, while technique II did not. $\mathrm{H}_{2} \mathrm{O}$ was used to decelerate gelation to add enzyme before hydrogel was formed. Technique II did not use $\mathrm{H}_{2} \mathrm{O}$ since the enzyme was poured directly to $\mathrm{Na}_{2} \mathrm{SiO}_{3}$, so that enzyme had reached base condition because it had 13 of $\mathrm{pH}$. This will be the major difference between the techniques. It can be concluded that technique I had maintained the neutral $\mathrm{pH}$ during the immobilization process, while technique II did not.

\subsection{Determination of immobilized enzyme in silica gel}

A biuret method is one of the efficient protein assay methods done based on the complexation between $\mathrm{Cu}^{2+}$ and protein's peptide bond. The formation of $\left[\mathrm{Cu}^{2+}\right.$-protein $]$ complex requires two peptide bonds and later forms a chelate compound with purple-colored. Its compound can be measured at a wavelength of $540 \mathrm{~nm}$. A standard curve will give information about the absorbance of BSA standard which has a linear equation for calculating contained-protein [12].

Table 3. Percentage of immobilized enzyme by soaking effect

\begin{tabular}{cc}
\hline Soaking & $\begin{array}{c}\text { Percentage of Immobilized } \\
\text { Enzyme (\%) }\end{array}$ \\
\hline $1^{\text {st }}$ & 67.71 \\
$2^{\text {nd }}$ & 59.27 \\
$3^{\text {rd }}$ & 57.27 \\
\hline
\end{tabular}

The research said that the soaking of an immobilized enzyme in the buffer solution caused a dissolving of an enzyme that could not be trapped by support [13]. Based on the Table 3, the percentage of immobilized lipase had slightly decreased after being soaked 3 times, indicating that the silica gel had completely trapped an enzyme.

\subsection{FTIR analysis}

The immobilized enzyme was characterized at 350 to $4000 \mathrm{~cm}^{-1}$. Silica gel without enzyme had to be blank as a comparison. The immobilized enzyme showed a broad peak of $3425.58 \mathrm{~cm}^{-1}$ indicating the existence of hydroxyl group (-OH). Normally, the hydroxyl group is indicated at $3500 \mathrm{~cm}^{-1}$. This highlighted an interaction between electropositive and hydroxyl groups, which was from the silanol group (Si-OH). Si-OH showed a sharp peak at 2854.65 and $2916.37 \mathrm{~cm}^{-1}$. There also was a sharp peak at $864.11,1$ 072.42 , and $1157.29 \mathrm{~cm}^{-1}$ indicating Si-O-Si vibration [14]. Immobilized lipase in silica gel had stronger interaction between siloxane and silanol group than silica gel blank, so the peak was sharper since the immobilized one had reacted with lipase. Compared to silica gel blank, there was no indication of $\mathrm{C}=\mathrm{N}$ and $\mathrm{C}=\mathrm{O}\left(1797.66 \mathrm{~cm}^{-1}\right)$ which are the protein groups [15].

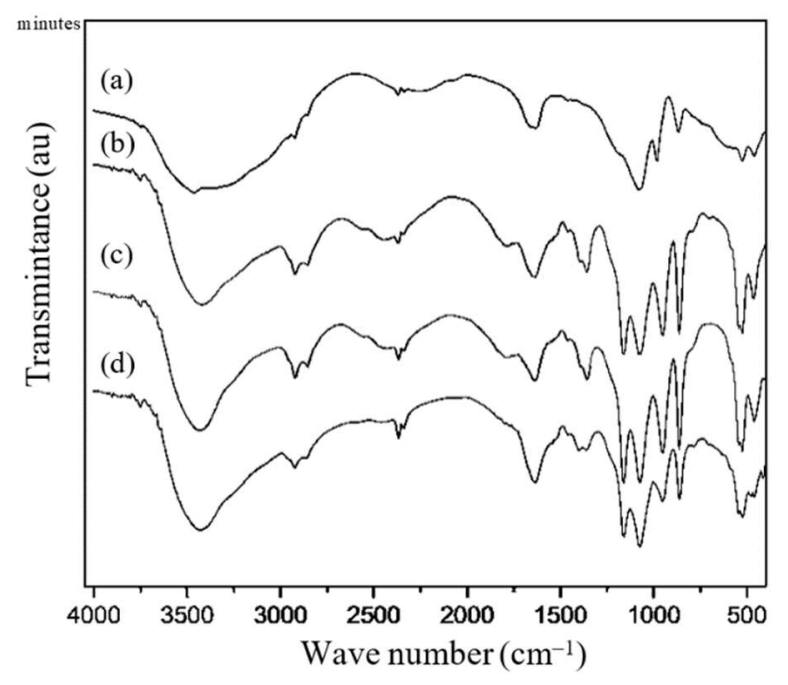

Fig. 1. FTIR Spectra of Silica Gel (a), Immobilized Enzyme 1:1 (b), 1:2 (c), and 2:1 (d).

\subsection{Activity assay}

\subsubsection{Hydrolysis of palm oil}

This assay was the first hydrolysis of palm oil. The result was shown at Figure 2. The samples consisted of two blanks, a free enzyme (E0) and six immobilized enzymes (E1-E6). Two blanks were blank 1 (B1: without enzyme) and blank 2 (B2: silica gel without enzyme). The other six were immobilized enzymes with the variations having mentioned before. Hydrolysis of oil can be shown from how much percentage of free fatty acid (FFA) was hydrolyzed, as the table below. It is shown that the immobilized enzyme had a percentage of FFA making it lower than the free enzyme since the 
silica gel had covered the enzyme's active site. Assumed that silica gel (B2) had no activity for hydrolyzing triglycerides as the enzyme had. From all 6 immobilized enzymes, E2 had a higher ability for hydrolyzing triglyceride into FFA. In other words, E2 had the best ratio for creating an immobilized enzyme in silica gel.

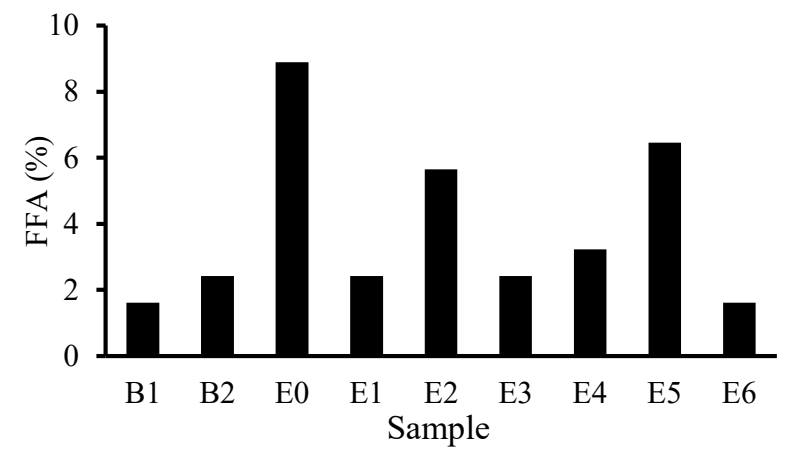

Fig. 2. Percentage of FFA hydrolyzed

\subsubsection{Reusability}

Based on the result was shown at Figure 3, E2 had lower percentage of FFA than E5 during the first hydrolysis. It was constant until the $3^{\text {rd }}$ cycle. Meanwhile, E5 had decreased until the $3^{\text {rd }}$ cycle.

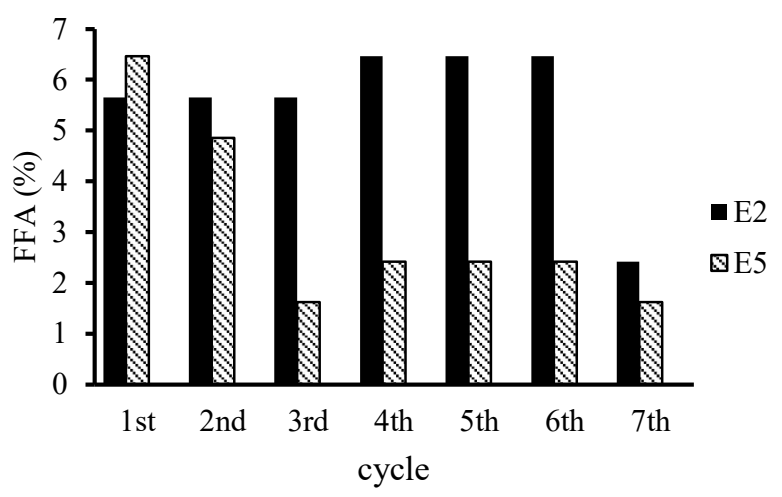

Fig. 3. Percentage of FFA after reused

Both of them had fluctuative percentage of FFA when reaching the $4^{\text {th }}$ cycle. When it reached the $7^{\text {th }}$ cycle, both of them had drastically decreased. Even so, both immobilized enzyme with different techniques were reusable until the $6^{\text {th }}$ cycle.

\section{Conclusion}

Immobilized lipase had the activity to hydrolyze palm oil as what the free lipase had, but it was less than free lipase and would decrease due to the continuous reuse. Compared to the free lipase, the immobilized lipase had the reusability until the $6^{\text {th }}$ cycle. This reusability of immobilized lipase may become its advantages as free lipase did not have one. The percentage of immobilized lipase in silica gel was $67.71 \%$, then decreased into $57.27 \%$ after being soaked for three times.
This research study was funded by the Ministry of Research, Technology, and Higher Education of the Republic of Indonesia (Ristekdikti - Indonesia) through the PDUPT Grant (2770/UN1.DITLIT/DIT-LIT/PT/ 2020).

\section{References}

1. S. Bhatia, Introduction to enzymes and their applications (2018).

2. S. Cantone,V. Ferrario, L. Corici, C. Ebert, D. Fattor, P. Spizzo, L. Gardossi, Chem. Soc. Rev., 42, 6262-6276 (2013)

3. A. Tathe, A.P.G. Nikalje, M. Ghodke, Nikalje, Asian Journal of Research in Chemistry, 4, 9, 13551360 (2011).

4. P.K. Robinson, Essays Biochem., 59, 1-41 (2015)

5. L. Xu, C. Ke, Y. Huang, Y. Yan, Catalysts, 6, 1-12 (2016).

6. D. Moentamaria, G. Againa, M.M. Ridhawati, A. Chumaidi, N. Hendrawati, J. Bahan alam Terbarukan, 5, 84-91 (2016) [in Bahasa Indonesia].

7. E.D.A. Cavalcanti-Oliveira, P.R. Da Silva, A.P. Ramos, D.A.G. Aranda, D.M.G. Freire, Enzyme Res. (2011).

8. L. Corici, V. Ferrario, A. Pellis, C. Ebert, S. Lotteria, S. Cantone, D. Voinovich, L. Gardossi, RSC Adv., 6, 63256-63270 (2016).

9. K. Larbi, Synthesis of High Purity Silicon from Rice Husk, Thesis, University of Toronto (CD), Canada (2010).

10. G. Iucci, G. Infante, L. Rossi, G. Polzonetti, N. Rosato, L. Avigliano, I. Savini, M.V. Catani, A.C. Palacios, J. Mater. Sci. Mater. Med., 15, 601606 (2004).

11. D. Pranowo, Nuryono, A. Agus, Jumina, R. Maryam, F. Setyabudi, Mycotoxins JSM, 67, 77-83 (2017).

12. N.K. Keppy, M.W. Allen, Thermo Fish. Sci., 8-9 (2000).

13. S.T. El-sayed, N.I. Omar, W.G. Shousha, Saudi Journal of Medical and Pharmaceutical Sciences, 4929, 1222-1229 (2017).

14. L. Simatupang, R. Siburian, P. Sitanggang, M. Doloksaribu, M. Situmorang, H. Marpaung, Rasayan J. Chem., 11, 819-827 (2018).

15. N.B. Carvalho, B.T. Vidal, A.S. Barbosa, M.M. Pereira, S. Mattedi, L.D.S. Freitas, Int. J. Mol. Sci., 19 (2018). 